TRANSFORMTIKA, Vol.17, No.2, January 2020, pp. 209-214

ISSN: 1693-3656,

journals.usm.ac.id/index.php/transformatika

page 209

\title{
Temperature and Humidity Monitoring Using DHT22 Sensor and Cayenne API
}

\author{
Whisnumurti Adhiwibowo ${ }^{1}$, April Firman Daru ${ }^{2}$, Alauddin Maulana Hirzan ${ }^{3}$ \\ ${ }^{1}$ Universitas Semarang \\ Jln. Soekarno Hatta, Tlogosari, Semarang, 024-6702757, e-mail: whisnu@usm.ac.id \\ ${ }^{2}$ Universitas Semarang \\ Jln. Soekarno Hatta, Tlogosari, Semarang, 024-6702757, e-mail: firman@usm.ac.id \\ ${ }^{3}$ Universitas Semarang \\ Jln. Soekarno Hatta, Tlogosari, Semarang, 024-6702757, e-mail: maulanahirzan@usm.ac.id
}

\section{ARTICLE INFO}

Article history:

Received 02 January 2020

Received in revised form 15 January 2020

Accepted 27 January 2020

Available online 31 January 2020

\begin{abstract}
Internet of Thing is a new technology which enables small processing-capable devices to capture or retrieve information from a sensor and send the data to the central computer. This technology is useful for any sector especially agriculture, IoT can be used as monitoring or/and controlling the condition inside the cultivation. There are many kinds of agriculture cultivations, some of them have strict conditions due to the growth requirements. Oyster mushroom cultivation is one of many cultivations which requires strict temperature and humidity needed by oyster mushroom to growth optimal. The temperature inside the cultivation must be within $25^{\circ} \mathrm{C}$ until $30^{\circ} \mathrm{C}$ and humidity within $70 \% \mathrm{RH}$ until $90 \% \mathrm{RH}$. Due to these strict requirements, the farmers required to check their cultivations every day and manually maintain the temperature and humidity, and this situation becomes a problem when the farmers own many cultivations. Hence, this research has a purpose to design an automatic monitoring system based on Internet of Things technology which utilizing the DHT22 sensor and Cayenne API as information retrieval medium to the computer. When using this device, the farmers can check their cultivation in the meantime without going inside the cultivation.
\end{abstract}

Keywords: Information of Things, DHT22, Cayenne, Monitoring, Information Retrieval 


\section{Introduction}

Implementation of communication technology such as Internet of Things technology in agriculture can help the farmers monitor the cultivation directly without being inside the cultivation. Internet of Technology enables the communication between processing-capable devices to be used as information exchange over a distance(1). With this technology, the farmers can retrieve the cultivation information with either a smartphone or a computer. Some cultivations should implement Internet of Things technology to help the farmers to monitor the condition inside the cultivation especially oyster mushrooms. Oyster mushroom cultivation is cultivation that needs strict temperature and humidity conditions to make oyster mushroom develop optimally.

Oyster mushroom cultivation requires a temperature between $25^{\circ} \mathrm{C}$ until $30^{\circ} \mathrm{C}$ and air humidity between $70 \%-90 \% \mathrm{RH}$ (relative humidity)(2)(3)(4). When not fulfilled, the oyster mushroom will not grow optimally until harvest season(5). Hence, these requirements posed a problem for farmers. The farmers are required to check the cultivation every day and control the temperature and humidity inside the cultivation. This becomes a problem when the farmers must take care of many cultivations at once. Controlling one of the cultivations might take a long time if the cultivation area is wide. When taking too long, the temperature and humidity conditions changed, and treatment becomes inefficient. Hence, this research has a purpose to design an automatic temperature and humidity monitoring system which utilize Internet of Things technology as communication media between nodes inside cultivation and the farmers.

This monitoring system utilizes a processing-capable device such as Raspberry $\mathrm{Pi}$ to retrieve information from a DHT22 sensor and send them to the farmers. Unlike the DHT11 sensor, the DHT22 sensor provides better accuracy for temperature and humidity. DHT22 relatively measures $4 \%$ more accurate for the temperature and $18 \%$ for the humidity $(6,7)(8)$. This system implements Cayenne API to provide temperature and humidity information transmission from the cultivation area. The farmers can check this information directly via an LCD attached to the device or via smartphone with the Cayenne app installed and connected to the internet. However, the system must be connected to the internet when accessing through a smartphone app.

\section{Research Method}

Some researchers have been working with a monitoring system which monitors the temperature and humidity. However, most of the researches on temperature and humidity control were not based on Internet of Things technology and equipped only with DHT11 sensors(9). The system made by the previous researches utilized Atmega as the microcontroller, instead of using a processing-capable device such as Raspberry Pi. Hence, information retrieval between a distance is almost impossible to do(10).

Besides that, another research utilized Arduino Mega as an information retrieving node which uses the SHT75 sensor. However, the information retrieved by this research system only limited to Windows-based phones(11). There is also humidity and temperature monitoring in the mushroom cultivation system which utilized Arduino UNO, and DHT11(12). There is a research for monitoring and controlling system which based on the web, this system utilized wireless sensor network such as Arduino Mega, and Raspberry Pi(13).

Many kinds of research have been improved on how the monitor system should be. There is a system that utilized the SHT11 sensor relay, and fuzzy logic to control the actuator inside the device. However, this system is not based on Internet of Things technology. Hence the communication between farmers and nodes is limited(14). Additional research of monitoring using PLC as control system resulting a controlled environment for mushroom to grow(15).

The automatic temperature and humidity monitoring system is designed according to the observation data from oyster cultivation. The gathered data from observation such as temperature and humidity are recorded as the base of development. 


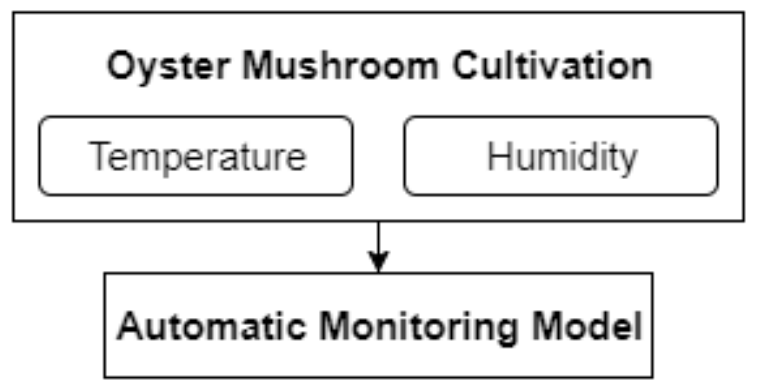

Figure 1. Oyster mushroom observation

The next step for the development is to design the automatic monitoring system based on Internet of Things technology. See figure below:

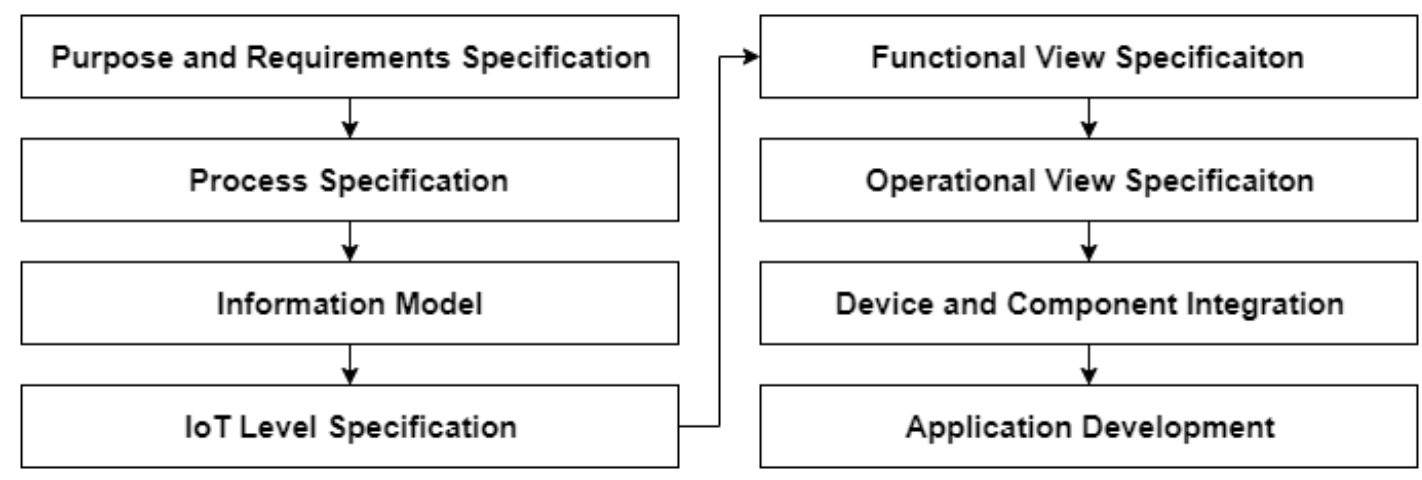

Figure 2 Internet of Things design methodology

This loT design methodology is a specialized method to develop loT device which meets users' criteria. Each phase in this design methodology describes the specification of loT devices such as requirements, loT process, data model, and even the application used for loT.

\section{Results and Analysis}

According to the loT design method, the result of an automatic monitoring system design is explained below:

\subsection{Purpose and Requirements Specification}

This IoT model has a purpose to monitor the temperature and humidity inside oyster mushroom cultivation in real-time. Hence, temperature and humidity data from the cultivation is required to model the automatic system.

\subsection{Process Specification}

This section explains how an automatic monitoring system does temperature and humidity monitoring in the cultivation. 


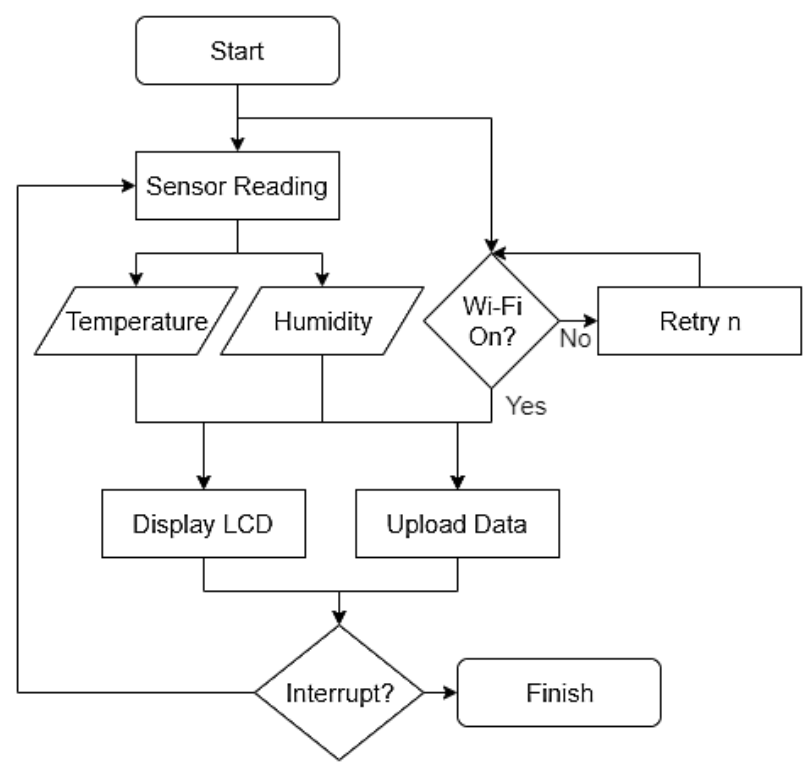

Figure 3. A process model for automatic monitoring system

This automatic monitoring model is working by reading temperature and humidity from a DHT22 sensor. The data obtained by the sensor is displayed to and LCD and to the server through the Cayenne API. This process repeats endlessly until the power interruption happened.

\subsection{Information Model Specification}

This section explains what kind of data model exists inside the cultivation and attributes owned by each of the components. See figure below:

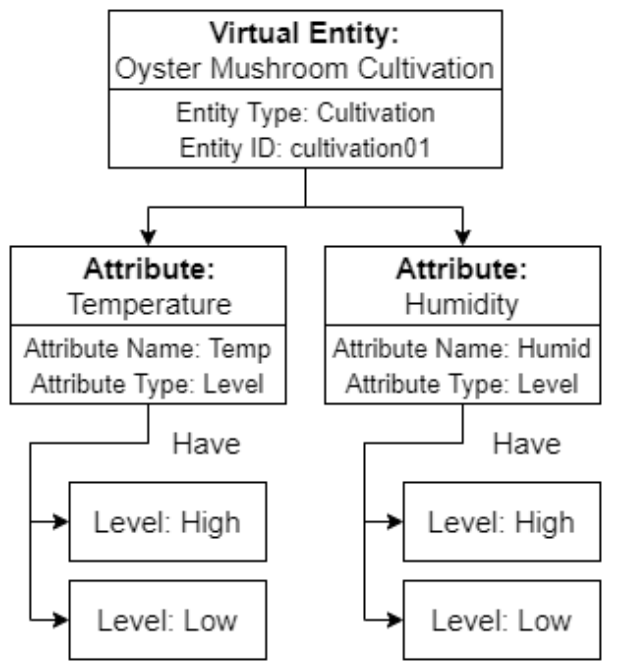

Figure 4. Information model for automatic monitoring system

The specifications for the information model used in the automatic monitoring system consist of Oyster Mushroom Cultivation as Virtual Entity, Temperature and Humidity as Attributes and each of them have two levels.

\subsection{Operational View Specification}

This section explains how an automatic monitoring system works on the real world; this reflects how each component communicates with others. See figure below:

TRANSFORMATIKA Vol. 17, No. 2, January 2020 : $209-214$ 


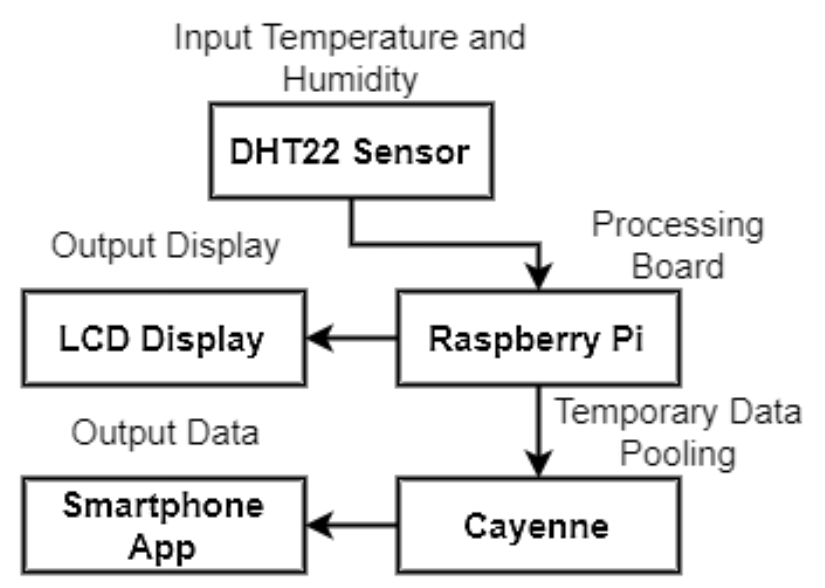

Figure 5. Automatic monitoring system operational view

The automatic monitoring system works by using DHT22 as an input sensor for cultivation, the information continues to Raspberry $\mathrm{Pi}$ for data processing. If the internet is connected, then nodes will send the information to the Cayenne server as well as LCD Display.

\subsection{Retrieved Data Result}

All retrieved data are exported CSV and used as data analysis for sensor validation and forecasting. Hence, the histogram of sample data is shown below:

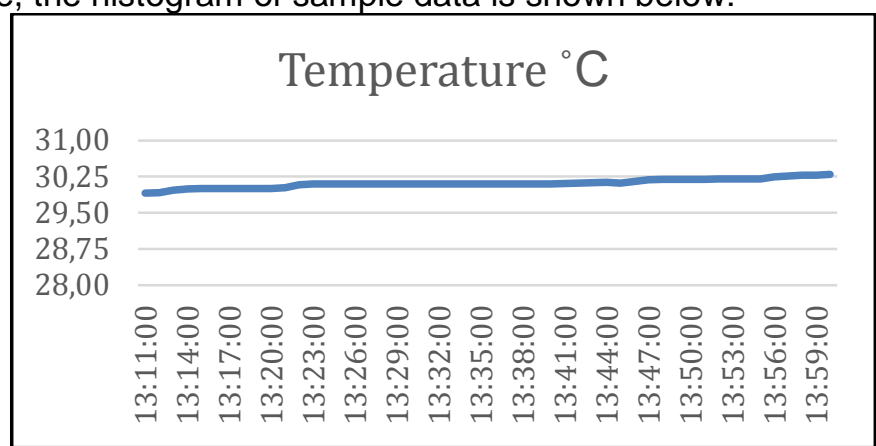

Figure 6. Temperature histogram data

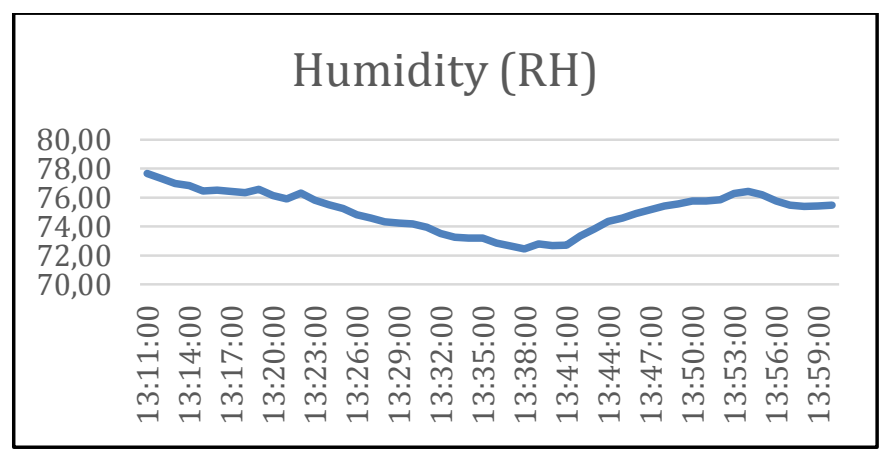

Figure 7. Humidity histogram data

According to the figures above, the sensor is successfully capturing the condition inside the cultivation within a certain time and the received data to the server through Cayenne. Based on the figures above, the automatic monitoring system captures the condition inside the cultivation every 3 minutes without fail.

Temperature and Humidity Monitorin Using DHT22 Sensor andCayenne API (Whisnumurti) 


\section{Conclusion}

According to the result obtained from the system, it can be concluded that the temperature and humidity monitoring system for oyster mushroom cultivation successfully captured the information inside the cultivation every 3 minutes. This can be proven by either download the data from the server or check the Cayenne app from a smartphone. The smartphone which can be used to monitor the nodes is not limited to Android only, but also IOSbased phones. When internet connectivity is not available, the farmers can check the condition through an LCD embedded in the device.

This system has many weaknesses such as no temperature and humidity regulation mechanism to ease the farmers, larger-scale monitoring for wider cultivation and heat camera detection to detect high temperatures for each cultivation media. Hence, the next research for this topic should add more complex features such as high-temperature detection, pest controls, mold detection, and a larger monitoring system.

\section{References}

1. Bari N, Mani G, Berkovich S. Internet of things as a methodological concept. In: Proceedings - 2013 4th International Conference on Computing for Geospatial Research and Application, COMGeo 2013. 2013.

2. National Horticulture Board. Oyster Mushroom [Internet]. Gurugram; 2006. Available from: http://nhb.gov.in/report files/oyster_Mushroom/OYSTER MUSHROOM.htm

3. Subbiah KA, Balan V. A comprehensive review of tropical milky white mushroom (Calocybe indica P\&C). Mycobiology. 2015.

4. Ragupathi V, Kumerasan S, Selvaraju S, Karthikeyan V, Karthikeyan C V. Optimizing the growth conditions and adopting new methods growing oyster and milky mushrooms in same conditions. Int J Herb Med. 2016;

5. Uddin MN, Yesmin S, Khan MA, Tania M, Moonmoon M, Ahmed S. Production of Oyster Mushrooms in Different Seasonal Conditions of Bangladesh. J Sci Res. 2010;

6. Liu T. Digital Humidity and Temperature sensor. Adfruit. 2016;

7. Saptadi AH. Perbandingan Akurasi Pengukuran Suhu dan Kelembaban Antara Sensor DHT11 dan DHT22. J INFOTEL - Inform Telekomun Elektron. 2014;

8. Queiroz TAF, Dias DL, Araújo PHM, Renan P, Jucá SCS. Sistema Embarcado Linux para Análise de Sensores de Temperatura DHT11 e LM35. Esc Reg Informática do Piauí. 2016;

9. Mahmud MSA, Buyamin S, Mokji MM, Abidin MSZ. Internet of things based smart environmental monitoring for mushroom cultivation. Indones J Electr Eng Comput Sci. 2018;

10. Triyanto A, Nurwijayanti N. Pengatur Suhu dan Kelembapan Otomatis Pada Budidaya Jamur Tiram Menggunakan Mikrokontroler ATMega16. J Kaji Tek Elektro Univ Suryadarma Jakarta. 2016;

11. Priharyanto, Eko I. Implementasi Pengontrol Serta Monitoring Suhu dan Kelembaban Pada Budidaya Jamur Menggunakan Windows Phone [Internet]. University of Muhammadiyah Malang; 2016. Available from: http://eprints.umm.ac.id/33586/

12. Giashinta P. Alat Pengatur Suhu Kelembaban dan Monitoring Masa Panen pada Budidaya Jamur Tiram Berbasis Arduino Uno. Universitas Negeri Yogyakarta. 2018.

13. Gowthaman NB, Priya N. IOT Based Smart Crop Monitoring in Farm Land. Imp J Interndisciplinary Res. 2018;

14. Ade Barlian Tandiono, Moch. Rusli, Muhammad Aziz Muslim. Pengendalian Suhu dan Kelembaban pada Budidaya Jamur Tiram dengan Menggunakan Metode Kontrol Logika Fuzzy. J EECCIS (Electrics, Electron Commun Control Informatics, Syst. 2016;

15. Watkar MS, A DAWANDE Assistant Professor PN, SURESH RODE Assistant Professor P, SHELKE Assistant Professor PS. AUTOMATIC MONITORING AND CONTROLLING SYSTEM USING PLC FOR MUSHROOM PLANT. NOVATEUR PUBLICATIONS International Journal of Research Publications in Engineering and Technology. 2017. 